\title{
Collaboration of Brca1 and Chk2 in tumorigenesis
}

\author{
John Peter McPherson, ${ }^{1,2,5,6}$ Bénédicte Lemmers, ${ }^{1,2,6}$ Atsushi Hirao, ${ }^{3}$ Anne Hakem, ${ }^{1,2}$ \\ Jacinth Abraham, ${ }^{1,2}$ Eva Migon, ${ }^{1,2}$ Elzbieta Matysiak-Zablocki, ${ }^{1,2}$ Laura Tamblyn,, \\ Otto Sanchez-Sweatman, ${ }^{2}$ Rama Khokha, ${ }^{2}$ Jeremy Squire, ${ }^{2}$ M. Prakash Hande, ${ }^{4}$ Tak W. Mak, ${ }^{1,2}$ and \\ Razqallah Hakem ${ }^{1,2,7}$

\begin{abstract}
${ }^{1}$ Advanced Medical Discovery Institute, Ontario Cancer Institute, Toronto, Ontario M5G 2C1, Canada; ${ }^{2}$ Department of Medical Biophysics, University of Toronto, Toronto, Ontario M5S 1A8, Canada; ${ }^{3}$ The Sakaguchi Laboratory of Developmental Biology, School of Medicine, Keio University, Shinjuku, Tokyo 160-8582, Japan; ${ }^{4}$ Department of Physiology,
\end{abstract} \\ Faculty of Medicine, National University of Singapore, 117597 Singapore
}

Disruption of Brca1 results in cellular demise or tumorigenesis depending on cellular context. Inactivation of p53 contributes to Brca1-associated tumor susceptibility. However the activation of p53-dependent checkpoint/apoptotic signaling in the absence of Brca1 is poorly understood. Here, we show that Chk2 inactivation is partially equivalent to p53 inactivation, in that Chk2 deficiency facilitates the development, survival, and proliferation of Brca1-deficient $\mathrm{T}$ cells at the expense of genomic integrity. Brca1 deficiency was found to result in Chk2 phosphorylation and the Chk2-dependent accumulation and activation of p53. Furthermore, inactivation of Chk2 and Brca1 was cooperative in breast cancer. Our findings identify a critical role for Chk2 as a component of the DNA damage-signaling pathway activated in response to Brca1 deficiency.

[Keywords: Breast cancer; T cell; genomic instability; apoptosis; cell cycle; proliferation]

Supplemental material is available at http://www.genesdev.org.

Received February 10, 2004; revised version accepted April 2, 2004.

BRCA1 germline mutations predispose women to early onset, familial breast and ovarian cancer (Scully and Livingston 2000; Welcsh et al. 2000; Venkitaraman 2002). Despite its role in maintenance of genome integrity (Kinzler and Vogelstein 1997), transcriptional regulation (Scully et al. 1997a; Somasundaram et al. 1997), and chromatin remodeling (Yarden and Brody 1999; Bochar et al. 2000; Pao et al. 2000; Wang et al. 2000; Welcsh et al. 2000), the exact mechanism of tumor suppression by BRCA1 remains to be defined. BRCA1 associates with proteins that function in DNA replication and repair (Scully et al. 1997b; Wang et al. 2000), transcriptional activation (Chapman and Verma 1996; Monteiro et al. 1996; Scully et al. 1997a; Li et al. 2000), and the DNA damage response (Scully et al. 1997b; Zhong et al. 1999; Li et al. 2000; Wang et al. 2000; Welcsh et al. 2000). Cells with mutant Brca1 display defects in survival and proliferation (Gowen et al. 1996; Hakem et al. 1996; Ludwig

${ }^{5}$ Present address: Department of Pharmacology, University of Toronto, Toronto, Ontario M5S 1A8, Canada.

${ }^{6}$ These authors contributed equally to this work.

${ }^{7}$ Corresponding author.

E-MAIL rhakem@uhnres.utoronto.ca; FAX (416) 204-2277.

Article published online ahead of print. Article and publication date are at http://www.genesdev.org/cgi/doi/10.1101/gad.1192704. et al. 1997; Shen et al. 1998), radiosensitivity (Shen et al. 1998; Welcsh et al. 2000), chromosomal abnormalities (Xu et al. 1999; Mak et al. 2000; Welcsh et al. 2000), p53 activation (Hakem et al. 1996), G2/M checkpoint loss (Larson et al. 1997; Xu et al. 1999), and impaired homologous recombination repair (Moynahan et al. 1999). Accordingly, the pleiotropic effects of BRCA1 mutation could be attributed to its involvement in DNA repair and transcriptional regulation.

Brca1-targeted disruption in mice results in embryonic lethality (Gowen et al. 1996; Hakem et al. 1996; Liu et al. 1996; Ludwig et al. 1997). To circumvent this limitation, conditional targeting strategies have been employed that facilitate the study of the consequences of Brcal disruption in vivo and ex vivo (Xu et al. 1999; Mak et al. 2000). Mice that are Brca1 $^{-1-}$ (Mak et al. 2000) carry a targeted null mutation of Brca1 restricted to the $\mathrm{T}$-cell lineage, thus bypassing the associated lethality of Brca1 germline disruption. Brca1 disruption in the T-cell compartment results in a drastic depletion of thymocytes and peripheral $\mathrm{T}$ cells, the accumulation of chromosomal abnormalities, and activation of p53. Thymocyte development of $\mathrm{tBrca1}^{-/-}$mice is restored in the absence of p53 or the presence of overexpressed antiapoptotic protein $\mathrm{Bcl} 2$ that antagonizes the $\mathrm{p} 53$ pathway. These findings suggest that genomic instability and p53 
activation due to the ablation of Brcal contribute to the observed defects in T-cell development, survival, and proliferation.

Although several studies have linked the compromised viability and genomic instability of Brcal-deficient cells to the activation of p53 by genome surveillance (Hakem et al. 1997; Shen et al. 1998; Mak et al. 2000; Xu et al. 2001; Cao et al. 2003), the molecular components that comprise this response are unclear. Recent studies of p53 have elucidated upstream signaling cascades that modulate its half-life, intracellular localization, and functional activity (Giaccia and Kastan 1998; Caspari 2000; Vousden and Lu 2002). DNA damage alters the phosphorylation status of p53 and other DNA damage response proteins by triggering molecular signaling cascades that include ATM, ATR, DNA-PK, Chk1, and Chk2 kinases (for review, see Rich et al. 2000; Zhou and Elledge 2000; Nyberg et al. 2002; Shiloh 2003). A component of these genome surveillance pathways, Chk2 (also known as Cds1, for review, see Bartek et al. 2001; McGowan 2002) has been identified as a tumor suppressor, as mutations in Chk2 have been implicated in familial cancer syndromes including Li-Fraumeni (Bell et al. 1999) and low penetrance breast cancer susceptibility (Meijers-Heijboer et al. 2002; Vahteristo et al. 2002). Several studies have elucidated an ATM-Chk2p53 DNA damage signaling cascade that is activated following DNA damage (Hirao et al. 2000; Bartek et al. 2001). As Chk2 functions in a DNA damage response pathway that result in p53 activation, we sought to determine the contribution of this kinase to phenotypes associated with Brcal deficiency. We demonstrate that deficiency in Chk2 partially mimics the loss of p53 and rescues the defective development, growth, and cellular demise of Brca1-deficient $\mathrm{T}$ cells at the expense of genomic instability and increased tumorigenicity. We have

\section{Thymocytes}

wild-type

tBrca1 ${ }^{-1}$

Chk2-

\section{tBrca1- Chk2-}

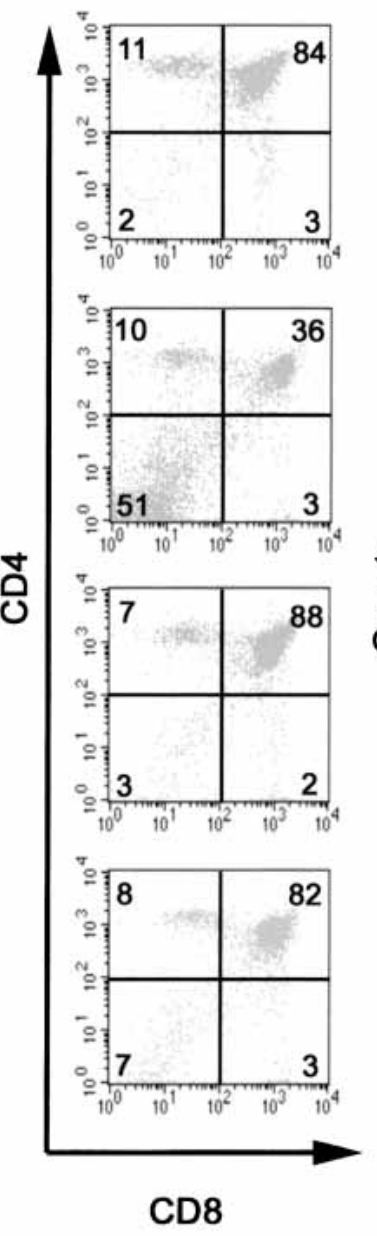

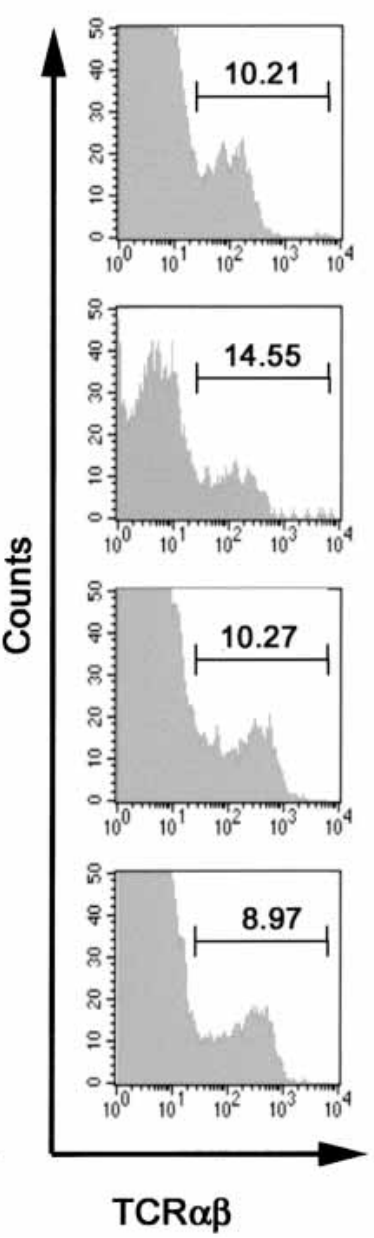

Lymph nodes
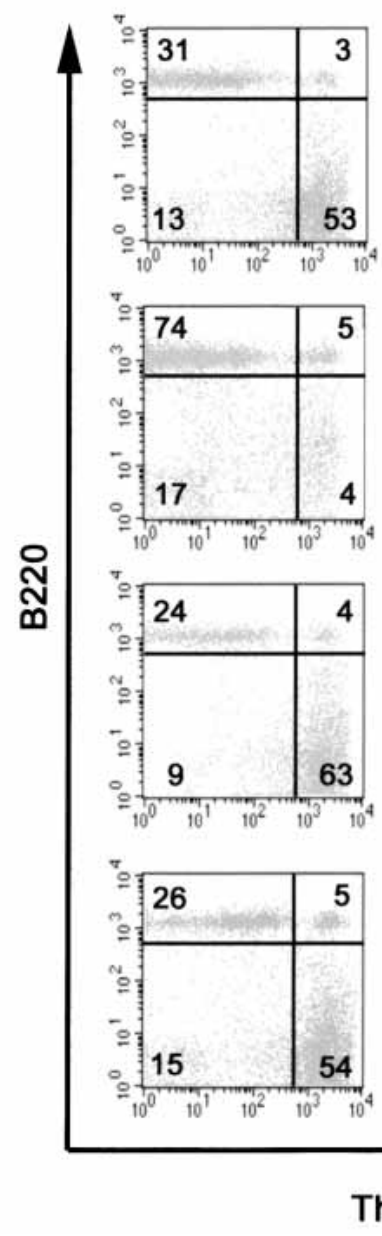

Spleen
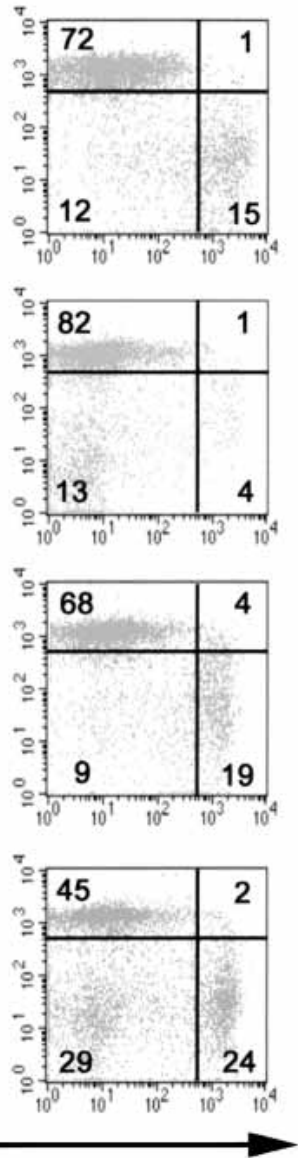

Thy-1

Figure 1. Chk2 deficiency restores the cellularity and development of the T-cell lineage in $t B r c a 1^{-/-}$mice. Thymocyte development

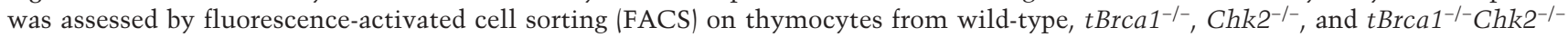
mice. Thymocytes were stained with antibodies against CD4, CD8, and TCR $\alpha \beta$. TCR $\alpha \beta$ expression was evaluated on gated CD4 ${ }^{+} \mathrm{CD} 8^{+}$ populations. Single-cell suspensions from spleen and lymph nodes were stained with antibodies against the T-cell lineage-specific marker Thy 1 and the B-cell lineage marker B220. Depicted FACScans with quadrant percentages are representive of least three independent experiments. 
Table 1. Aneuploidy and chromosomal abnormalities in $\mathrm{tBrcal}^{-/-}$peripheral T-cells

\begin{tabular}{|c|c|c|c|c|c|c|c|c|}
\hline Genotype & $\begin{array}{c}\text { Metaphases } \\
\text { analyzed }\end{array}$ & $\begin{array}{l}\text { Chromosomes } \\
\text { per metaphase }\end{array}$ & $\begin{array}{l}\text { Aneuploid } \\
\text { cells }(\%)\end{array}$ & $\begin{array}{l}\text { Total end- } \\
\text { to-end } \\
\text { fusions }{ }^{\mathrm{b}, \mathrm{c}}\end{array}$ & $\begin{array}{l}\text { Tri-radial-like } \\
\text { structures }^{\mathrm{b}}\end{array}$ & $\begin{array}{c}\text { Chromosome } \\
\text { breaks }^{\mathrm{b}}\end{array}$ & $\begin{array}{c}\text { Chromatid } \\
\text { breaks }^{\mathrm{b}}\end{array}$ & Fragments ${ }^{\mathrm{b}, \mathrm{d}}$ \\
\hline$p 53^{-/-}$ & 47 & $\begin{array}{c}39.2 \pm 2.7 \\
(26-40)\end{array}$ & 17.0 & $\begin{array}{c}0.06 / \text { cell } \\
6.38 \% \text { of } \\
\text { cells }\end{array}$ & 0 & $\begin{array}{c}0.02 / \text { cell } \\
2.13 \% \text { of } \\
\text { cells }\end{array}$ & $\begin{array}{c}0.06 / \text { cell } \\
4.26 \% \text { of } \\
\text { cells }\end{array}$ & $\begin{array}{l}0.15 / \text { cell } \\
12.77 \% \text { of } \\
\text { cells }\end{array}$ \\
\hline $\begin{array}{c}\text { tBrcal } \\
\text { p553-/- }\end{array}$ & 46 & $\begin{array}{c}38.1 \pm 6.7 \\
(24-56)\end{array}$ & 60.9 & $\begin{array}{l}0.87 / \text { cell } \\
67.4 \% \text { of } \\
\text { cells }\end{array}$ & $\begin{array}{c}0.57 / \text { cell } \\
41.3 \% \text { of } \\
\text { cells }\end{array}$ & $\begin{array}{c}0.33 / \text { cell } \\
21.7 \% \text { of } \\
\text { cells }\end{array}$ & $\begin{array}{c}0.44 / \text { cell } \\
34.8 \% \text { of } \\
\text { cells }\end{array}$ & $\begin{array}{l}0.70 / \text { cell } \\
45.7 \% \text { of } \\
\text { cells }\end{array}$ \\
\hline Chk2 $^{-/-}$ & 136 & $\begin{array}{c}39.93 \pm 0.4 \\
(36-40)\end{array}$ & 4.0 & 0 & 0 & $\begin{array}{l}0.02 / \text { cell } \\
2.03 \% \text { of } \\
\text { cells }\end{array}$ & $\begin{array}{l}0.01 / \text { cell } \\
1.35 \% \text { of } \\
\text { cells }\end{array}$ & 0 \\
\hline $\begin{array}{l}\text { tBrcal } \\
\text { Chk2 }^{-/-}\end{array}$ & 148 & $\begin{array}{c}39.47 \pm 1.4 \\
(32-40)\end{array}$ & 25.7 & $\begin{array}{c}0.14 / \text { cell } \\
11.03 \% \text { of } \\
\text { cells }\end{array}$ & $\begin{array}{l}0.17 / \text { cell } \\
13.97 \% \text { of } \\
\text { cells }\end{array}$ & $\begin{array}{c}0.07 / \text { cell } \\
6.62 \% \text { of } \\
\text { cells }\end{array}$ & $\begin{array}{l}0.09 / \text { cell } \\
8.09 \% \text { of } \\
\text { cells }\end{array}$ & $\begin{array}{l}0.21 / \text { cell } \\
13.97 \% \text { of } \\
\text { cells }\end{array}$ \\
\hline
\end{tabular}

Results shown are pooled from analyses of metaphase spreads from activated T-cell populations of at least three different mice per genotype.

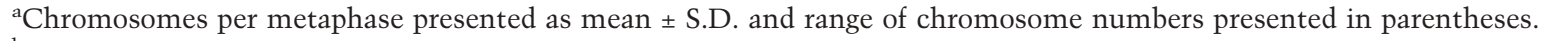

${ }^{\mathrm{b}}$ The incidence per cell is indicated in the upper row, the percentage of cells with abnormalities is indicated in the lower row.

'Includes Robertsonian fusionlike configurations, telomere associations, dicentric chromosomes, and ringlike structures.

${ }^{\mathrm{d} I n c l u d e s}$ centric and acentric fragments.

also identified an important role for Chk2 in suppressing Brcal-associated breast cancer.

\section{Results}

To assess genetic interplay between Brcal and Chk2 in vivo, mice with a conditional disruption of Brca1 (Mak et al. 2000) in the T-cell lineage (LckCre Brca1 ${ }^{f l / f 1}$ "tBrca1-/-") or mammary epithelium (WapCre Brca1 fl/f1 "mBrca1 ${ }^{-/-")}$ ) and Chk2 ${ }^{-/-}$mice (Hirao et al. 2002) were intercrossed to obtain mice deficient in both Brcal and Chk2 in the T-cell lineage ( $\left.\mathrm{Brca1}^{-/-} \mathrm{Chk}^{-/-}\right)$and mammary epithelium ( $\left.\mathrm{Brcal}^{-/-} \mathrm{Chk2}^{-/-}\right)$. Thymocyte development in $\mathrm{tBrCa1}^{-/-}$mice (Mak et al. 2000) is compromised and the total number of $\mathrm{T}$ cells is markedly reduced (Fig. 1; Supplementary Table 1). Chk2 deficiency does not markedly impact total thymus cellularity (Hirao et al. 2000, 2002), although a slight increase in the absolute numbers of $\mathrm{CD}^{-} \mathrm{CD} 8^{-}$population was detected (Fig. 1; Supplementary Table 1). The defective cellularity of the $\mathrm{CD} 4^{+} \mathrm{CD} 8^{+}, \mathrm{CD}^{+}$, and $\mathrm{CD} 8^{+}$subsets in Brcal-deficient thymocytes was found to be Chk2-de-

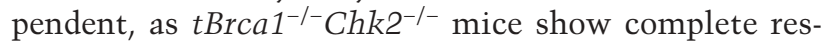
toration of all thymocyte and peripheral T-cell populations (Fig. 1; Supplementary Table 1).

tBrca1 ${ }^{-/-}$thymocytes exhibit increased apoptotic response to $\gamma$-irradiation ex vivo (Mak et al. 2000). This radiosensitivity is p53 dependent, as it is rescued in a p53 null background. Chk2 $2^{-/-}$thymocytes exhibit radioresistance compared with wild-type thymocytes (Hirao et al. 2000, 2002; Takai et al. 2002). The radiosensitivity of tBrca1 ${ }^{-/-}$thymocytes was also found to be dependent on Chk2, as $\mathrm{Brra1}^{-/-} \mathrm{Chk2}^{-/-}$thymocytes and Chk2 ${ }^{-/-}$thymocytes show equivalent resistance when assessed $8 \mathrm{~h}$ or $24 \mathrm{~h}$ after $\gamma$-irradiation (Fig. 2A,B). The proliferation impediment exhibited by $t B r c a 1^{-/-}$peripheral $\mathrm{T}$ cells following activation with anti-CD3 $\varepsilon+$ IL-2 or anti-
CD $3 \varepsilon+$ anti-CD28 was attenuated in the absence of Chk2 (Fig. 2C,D). The G1 + G2/M-phase arrest in anti$\mathrm{CD} 3+\mathrm{IL}-2$ activated $t \mathrm{Brca1} 1^{-/-}$cells was reversed in the absence of Chk2, suggesting that the reversal of the proliferation impediment was at least partially the result of attenuation of the cell cycle arrest (Fig. 2E).

Chk2 is phosphorylated and activated in response to DNA damage, resulting in the stabilization and activation of p53 (Chehab et al. 2000; Shieh et al. 2000; Hirao et al. 2002; Takai et al. 2002). Increased steady-state levels of p53 and its downstream transcriptional targets p 21 and bax were observed in Brcal-deficient thymocytes (Fig. 2F). The absence of Chk2 was found to attenuate the steady-state levels of p53, p21, and bax in thymocytes deficient in Brcal, indicating the involvement of Chk2 in mediating the effect of Brcal deficiency on p53. Increased phosphorylation levels of Chk2 were observed in Brcal deficient thymocytes, indicative of a role for Chk2 activity in the increased steady-state level of p53 in Brcal-deficient thymocytes (Fig. 2G). Irradiation-dependent phosphorylation of Chk2 was not affected by Brca1 mutation in thymocytes (Fig. 2G). These findings indicate that Chk2 inactivation facilitates the survival and proliferation of Brcal-deficient $\mathrm{T}$ cells by attenuating p53-dependent apoptosis and cell cycle arrest.

Brcal deficient thymocytes exhibit increased levels of spontaneous genomic instability (Mak et al. 2000). As genomic instability normally leads to stabilization and activation of $\mathrm{p} 53$, the attenuation of p53 activation in tBrca1 ${ }^{-/-} \mathrm{Chk}^{-/-} \mathrm{T}$ cells could be the result of a reversal in the genomic instability phenotype inherent in Brcaldeficient cells. However, the frequency of chromosomal breaks, fusions, tri-radials, and aneuploidy was markedly increased in $\mathrm{tBrCa1}^{-/-} \mathrm{Chk}^{-/-}$peripheral $\mathrm{T}$ cells compared with Chk2-/- cells (Fig. 3; Table 1), indicative of the impaired DNA damage response in the absence of Chk2. Interestingly, the spectrum of chromosomal ab- 
A

B

24h
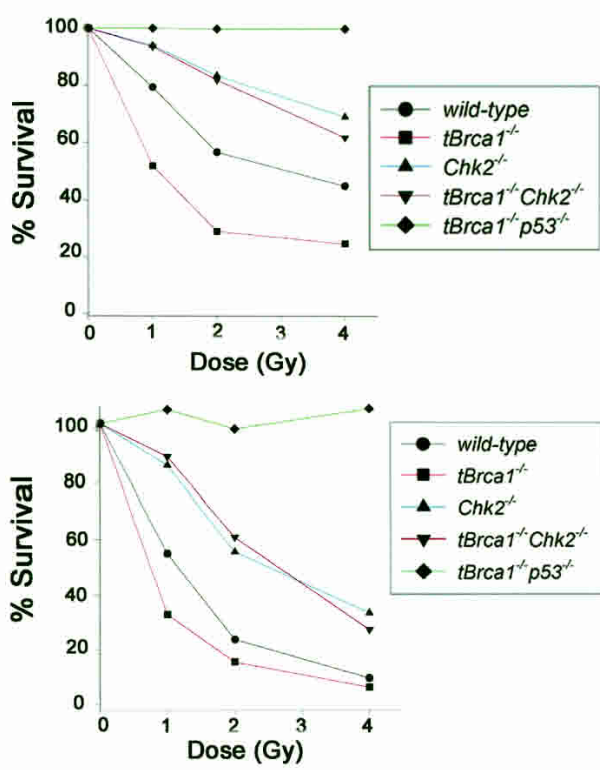

C

$48 \mathrm{~h}$
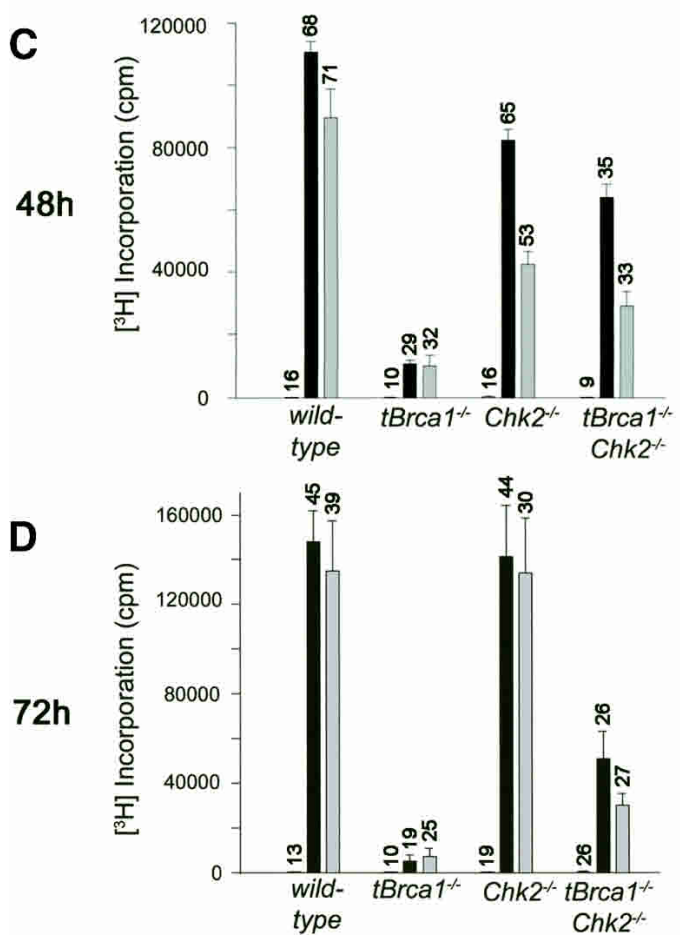

E

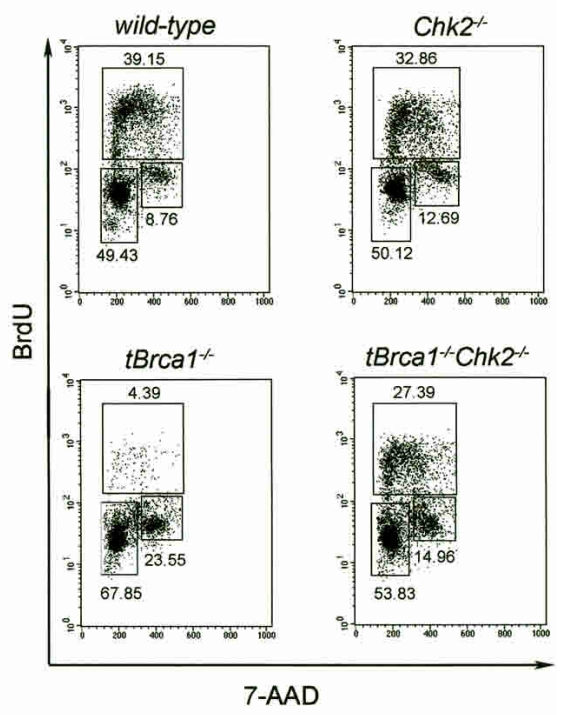

$\mathbf{F}$

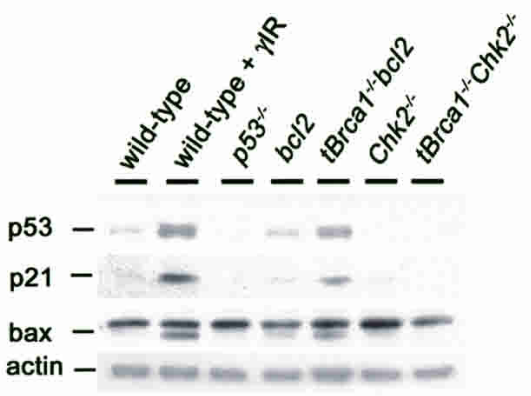

G

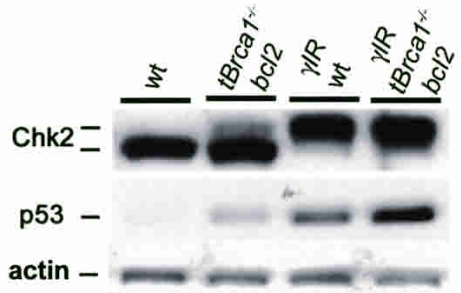

Figure 2. Chk2 deficiency rescues cellular outcomes associated with Brcal deficiency. $(A, B)$ Impact of Chk2 inactivation on radiosensitivity associated with Brcal deficiency. Cell viability of thymocytes ex vivo was measured by Annexin V-FITC and PI costaining and flow cytometry at $8 \mathrm{~h}(A)$ and $24 \mathrm{~h}(B)$ following the indicated doses of $\gamma$-irradiation. $(C, D)$ Cell viability and proliferation of untreated (white bars), anti-CD3 $\varepsilon+$ IL-2-activated (black bars), and anti-CD3 $\varepsilon+$ anti-CD28-activated (gray bars) purified peripheral T cells. Cells were pulsed after $48 \mathrm{~h}(C)$ or $72 \mathrm{~h}(D)$ with $1 \mu \mathrm{Ci}$ of $\left[{ }^{3} \mathrm{H}\right]$ thymidine per well for $18 \mathrm{~h}$. The data presented are from triplicate cultures $( \pm$ S.D.) and depict results representative of three independent experiments. Percentages of viable cells are indicated as numerical values for each treatment. $(E)$ Cell-cycle profiles of anti-CD3 activated T cells. The percentages of cells in the G1, S, and G2/M phases are indicated. Results shown are representative of three independent experiments. $(F, G)$ Western analysis of Chk2, p53, p21, bax, and actin of whole-cell extracts from thymocytes of the indicated genotypes. To facilitate the comparison of developmentally equivalent Brca1-deficient and control thymocytes, extracts were prepared from $t B r c a 1^{-/-} E \mu-b c l-2-36\left(t B r c a 1^{-/-} b c l-2\right)$ and $E \mu-b c l-2-36$ (bcl-2) thymocytes (Mak et al. 2000). 
McPherson et al.

Figure 3. Chk2 or p53 inactivation facilitates the development, survival, and proliferation of Brcal-deficient $\mathrm{T}$ cells at the expense of genomic integrity. Chromosomal aberrations in representative metaphase spreads from $\mathrm{p53}^{-/-}, \mathrm{tBrca1} 1^{-/-} \mathrm{p}^{-1-} 3^{--} \mathrm{Chk}^{-/-}$, and $\mathrm{tBrCa1}^{-/-} \mathrm{Chk}^{-/-}$ peripheral $\mathrm{T}$ cells. (b) Chromosome break; (d) dicentric fusion; $(\mathrm{r})$ ring chromosome; $(\mathrm{t})$ tri-radial-like structure.

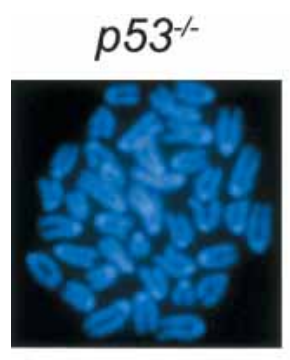

Chk2-1
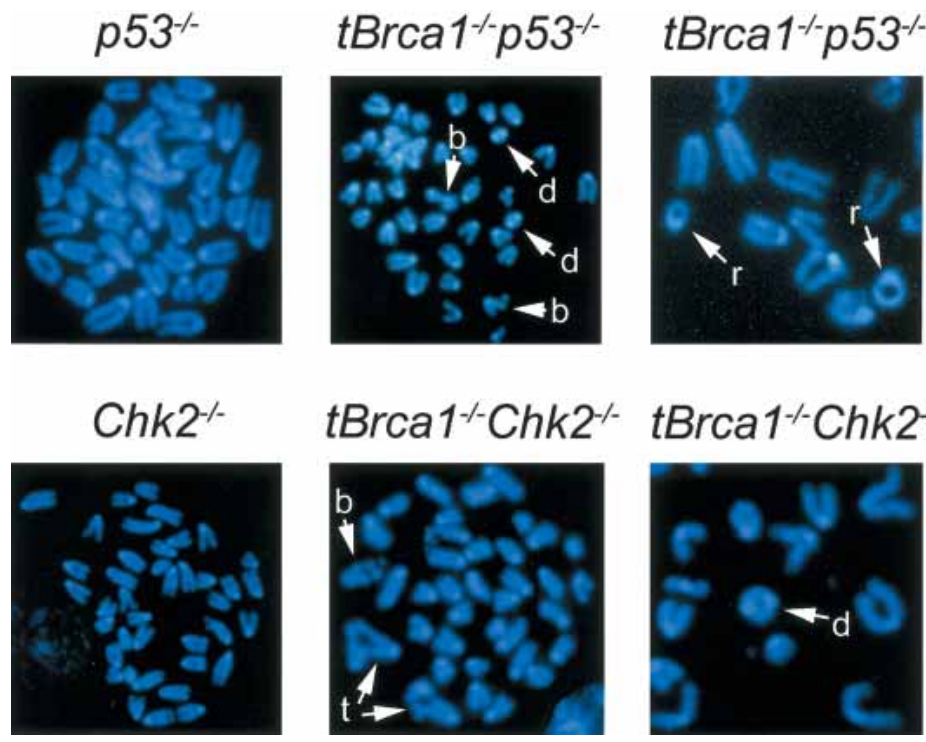

tBrca1\%Chk2-
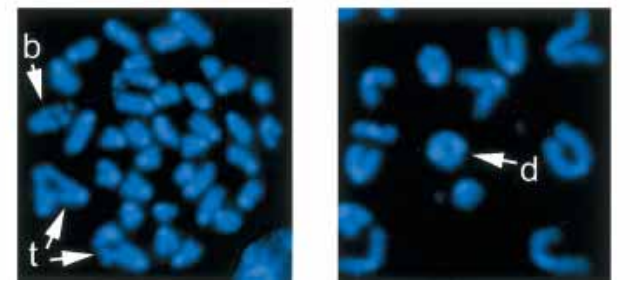

normalities was consistent with those obtained from tBrca1 ${ }^{-/}$p $53^{-/-}$-activated $\mathrm{T}$ cells; however, the frequency of all observed chromosomal abnormalities was lower (Table 1). Thus, loss of Chk2 reverses apoptosis and cell-cycle defects but not the genomic instability associated with Brcal mutation in T cells.

Previous studies have demonstrated that loss of p53 cooperates with Brcal deficiency in tumorigenesis (Cressman et al. 1999; Xu et al. 1999, 2001; Ludwig et al. 2001). In the thymus, Brca1 and p53 mutations were found to potentiate the formation of thymic lymphomas. Complete penetrance $(100 \%)$ and decreased latency of tumor development was observed in $\mathrm{tBrca1}^{-/-}$ $p 53^{-/-}$mice $(p<0.0001)$, and the majority of these were moribund or died by 3 mo of age (Fig. 4A,E) compared with $t \mathrm{BrCa1}^{+/-} \mathrm{p} 53^{-/-}$and $\mathrm{p} 53^{-/-}$mice, which develop lymphomas or other tumors after $\sim 6$ mo of age, as anticipated from previous studies (Donehower et al. 1992). The rescue of thymocyte development and abrogation of p53 checkpoint-dependent responses in $\mathrm{tBrca1^{-/ }}$ p53-/and $\mathrm{tBrCa1}^{-/-} \mathrm{Chk2}^{-/-}$would predict a similar cooperativity in tumorigenesis in the concomitant absence of Brcal and Chk2. Although only $12 \%$ of $\mathrm{tBrca1}^{-1-}$ mice (4/33; Fig. 4B-D) and no Chk2 ${ }^{-/-}(0 / 20)$ succumbed to tumors after $400 \mathrm{~d}$ of observation, $32 \%$ of $\mathrm{tBrca1}^{-/-}$ $\mathrm{Chk2}^{-/-}$mice (7/22) succumbed to thymic lymphomas at an earlier onset (by $180 \mathrm{~d}, p=0.0155$; Fig. 4B,F). $t \mathrm{Brca1}^{-/-}$ $\mathrm{Chk2}^{-/-}$lymphomas (and $\mathrm{tBrCa1^{-/ }} \mathrm{p}^{-3^{-/-}}$lymphomas) were observed to be restricted to the thymus and were not observed to invade other organs such as the spleen and liver. The small proportion of tumor-burdened tBrca1 $1^{-/-}$mice did not develop thymic lymphomas, but instead exhibited lymphomas in peripheral lymphoid compartments that invaded the liver, lungs, and kidney. The incomplete penetrance in the tumor-prone phenotype suggests that some of the p53 tumor suppressor functions are retained in the absence of Chk2.

To determine whether Chk2 and Brcal cooperativity is relevant to breast cancer, we monitored cohorts of
mBrca1 ${ }^{-/-}, \mathrm{Chk2}^{-/-}$, and $\mathrm{mBrca1} 1^{-/-} \mathrm{Chk2}^{-/-}$breeding females. $\mathrm{mBrca1^{-/- }}$ females exhibited only a mild predisposition to breast cancer development $(12 \%, n=17$, mean age was $582 \mathrm{~d}$ ), whereas no mammary tumors were observed in $\mathrm{mBrCa1}^{+/-} \mathrm{Chk2}^{-/-}$and $\mathrm{Chk2}^{-/-}$females. In contrast, the frequency and onset of breast tumorigenesis was increased in $\mathrm{mBrca1}^{-/-} \mathrm{Chk2}^{-/-}$females compared with $\mathrm{mBrca1}^{-/-}$females $(p<0.0001$; Fig. $5 \mathrm{M})$, as $50 \%$ of $\mathrm{mBrca1}^{-/} \mathrm{Chk2}^{-/-}$breeding females developed breast carcinoma ( $n=8$, mean age was $424 \mathrm{~d}$; Fig. 5A-D,M).

Similar to $\mathrm{mBrca1}^{-/-} \mathrm{Chk2}^{-/-}$females, $\mathrm{mBrca1}^{-/-}$ $\mathrm{p5}^{+/-}$females exhibited a marked predisposition to breast cancer neoplasia compared with $\mathrm{mBrca1}^{-/-}$mice $\left(p<0.0001\right.$; Fig. 5E-H,N). Eighty percent of $\mathrm{mBrca1}^{-/-}$ $p 53^{+/-}$breeding females were observed to develop breastbreast carcinomas $(n=5$, mean age was $385 \mathrm{~d})$. The susceptibility of female $\mathrm{mBrca1^{-/ }} \mathrm{p}^{-1-}$ mice to mammary neoplasia could not be assessed, as these mutants often succumb to other tumors prior to the completion of their first pregnancy. The survival of $\mathrm{mBrca1} 1^{-/} \mathrm{p} 53^{-/-}$ mice was significantly decreased as $38 \%$ of males (11/29) and $67 \%$ of mated females $(10 / 15)$ succumbed to tumors by $6 \mathrm{mo}$ of age (Fig. $5 \mathrm{~N}$ ). Interestingly, in contrast to $p 53^{-/-}$mice that predominantly develop lymphomas, about half of the tumors from $\mathrm{mBrca1}{ }^{-/} p 53^{-/-}$mice were carcinomas (5/11 tumors analyzed were carcinomas of the skin, salivary gland, or colon, whereas $6 / 11$ tumors analyzed were lymphomas of $\mathrm{T}$ or B cell origin; Fig. 5I-L).

Mammary tumors from either $\mathrm{mBrca1}^{-/-} \mathrm{Chk2}^{-/-}$or mBrca1 ${ }^{-/}{ }^{-} 53^{+/-}$females exhibited histological features characteristic of acinar adenocarcinomas (2/4 from mBrca1 ${ }^{-/} \mathrm{Chk2}^{-/-}$mice and $4 / 4$ from $\mathrm{mBrca1}^{-/} \mathrm{p}^{-1} 3^{+/-}$ mice) of varying differentiation status, with tumor cells typically organized in small glandular structures containing a central lumen and occasional luminal secretions (Fig. 5A,B,D-H). Two of the four mammary carcinomas obtained from $\mathrm{mBrca1^{-/ }} \mathrm{Chk2}^{-/-}$mice also displayed regions of squamous differentiation, containing 
A

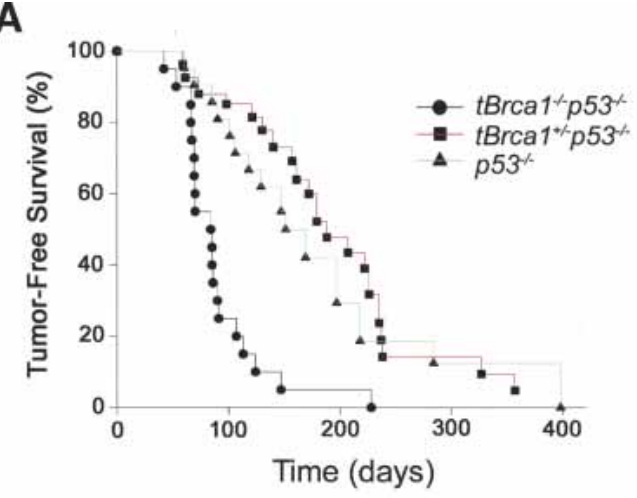

B

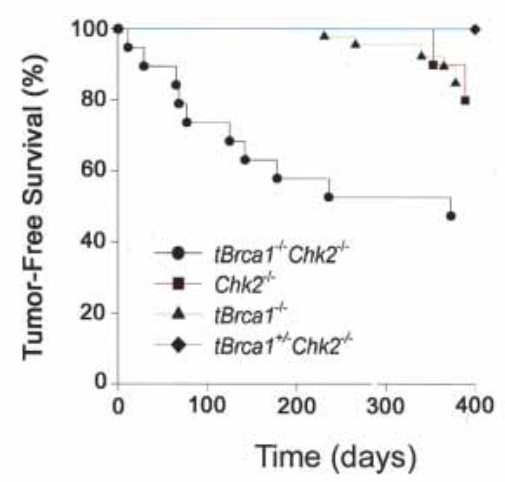

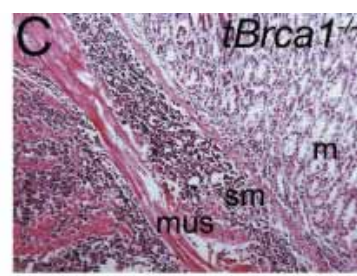
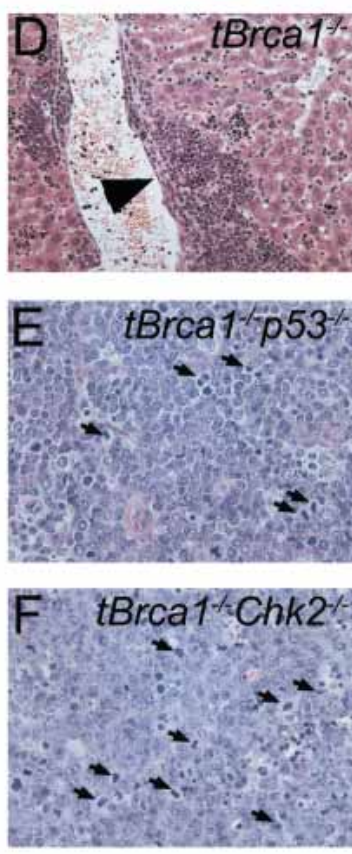

Figure 4. p53 or Chk2 deficiency synergizes with Brcal deficiency in the onset and frequency of thymic lymphomas. (A) KaplanMeier analysis of $p 53^{-1-}$ cohort survival according to Brcal deficiency in the T-cell compart-

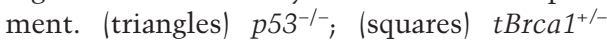
p53 ${ }^{-/-}$; (circles) $\mathrm{tBrca1}^{-/} \mathrm{p} 53^{-/-}$. Data shown

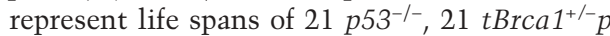
$53^{-/-}$, and $20 \mathrm{tBrca1}^{-/-} \mathrm{p53^{-/- }}$ mice. (B) KaplanMeier analysis of $\mathrm{tBrCa1}^{-/-}, \mathrm{Chk2}^{-/-}$, and tBrca1 ${ }^{-1-} \mathrm{Chk2}^{-/-}$cohort survival. (triangles) tBrca1 ${ }^{-1-}$; (squares) $\mathrm{Chk2}^{-/-}$; (circles) $\mathrm{tBrca1}^{-1}$ ${ }_{-} \mathrm{Chk}^{-/-}$. Data shown represent life spans of 33 $\mathrm{tBrCa}^{-1-}$ mice $(4$ moribund with lymphoma, 1 with infection), $20 \mathrm{Chk}^{-/-}$mice (4 moribund with infection), $22 \mathrm{tBrca1}^{-/-} \mathrm{Chk}^{-/-}$mice (7 moribund or dead from thymic lymphoma, 3 moribund with infection) and $8 \mathrm{tBrCa}^{+/-}$ Chk2 $^{-1-}$ mice monitored for 400 d. (C) Histological cross-section of invasive gastric lymphoma in $\mathrm{tBrCa}^{-/-}$mouse $(\mathrm{H} \& \mathrm{E}$ stain, original magnification $\times 100)$. The architecture of the submucosa $(\mathrm{sm})$ and muscle layers (mus) is altered by heavy infiltration of dark-staining neoplastic mononuclear cells. The gastric mucosa $(\mathrm{m})$ is preserved. $(D)$ Hepatic infiltration (arrow) of $t \mathrm{BrCa}^{-/-}$splenic lymphoma. $(E, F)$ Representative histological cross-sections of $\mathrm{tBrCa}^{-/-}$ p53 $3^{-/-}(E)$ and $\mathrm{tBrCa1}^{-/-} \mathrm{Chk}^{-/-}(F)$ thymic lymphomas (H\&E stain) with various mitotic figures demarcated by arrows. keratin pearls (Fig. 5C). Local infiltration into the adjacent soft tissue without metastatic invasion into the lungs or the lymphatic system was observed.

\section{Discussion}

Brcal-deficient cells exhibit genomic instability that results in p53 transactivation and compromised cell viability; however, the molecular components that comprise this response are yet to be elucidated (Hakem et al. 1997; Shen et al. 1998; Mak et al. 2000; Xu et al. 2001; Cao et al. 2003). The targeted disruption of Brca1 is often incompatible with cell viability, a finding that would appear incompatible with a role in tumor suppression (Venkitaraman 2002). However, the spontaneous chromosomal instability in Brca1-deficient cells might facilitate neoplastic transformation in cells with compromised responses to DNA damaging signaling through p53. Tumorigenesis in the absence of BRCA1 is facilitated by p53 deficiency; however, not all tumors from BRCA1 mutation carriers contain mutant $p 53$, indicative of the existence of alternative pathways that facilitate transformation (Crook et al. 1997; Greenblatt et al. 2001).

Our findings indicate the loss of p53-dependent responses mediated by Chk2 may be critical for survival, development, and tumor progression triggered by loss of
Brcal function. Loss of Chk2 does not rescue the phenotype of the Brcal-deficient $T$ cells to the same extent as loss of p53. This indicates that Chk2 mediates only a subset of p53 function. Chk2 is a component of the network of genome-surveillance pathways that coordinate cell-cycle progression with DNA repair and cell survival or death (Bartek et al. 2001; McGowan 2002). Chk2-/cells are radioresistant and show defects in $\gamma$-irradiationinduced apoptosis (Hirao et al. 2000, 2002; Takai et al. 2002). The mechanism whereby Chk2 facilitates radiation-induced apoptosis is poorly understood, but is thought to involve phosphorylation and stabilization of p53 (Chehab et al. 2000; Hirao et al. 2000, 2002; Shieh et al. 2000; Takai et al. 2002) or in some cases, phosphorylation of PML (Yang et al. 2002). In addition, Chk2-dependent signaling impacts various p53-dependent or p53independent checkpoints in response to $\gamma$-irradiation (Hirao et al. 2000, 2002; Bartek et al. 2001; Falck et al. 2001; Brown et al. 2002; Jack et al. 2002; McGowan 2002; Takai et al. 2002; Yang et al. 2002). Both Chk2 and p53 mutations have been implicated in the development of Li-Fraumeni syndrome (Malkin et al. 1990; Srivastava et al. 1990; Bell et al. 1999). Unlike p53-deficient mice, Chk2-deficient mice are not susceptible to the spontaneous development of tumors (Hirao et al. 2000, 2002). However, the loss of Chk2 may compromise a "gate- 
McPherson et al.

Figure 5. Tumor formation in $\mathrm{mBrca1}^{-/-}$ mice. $(A-D)$ Representative histology of mammary carcinomas from $\mathrm{mBrca1}^{-/-}$ Chk2-/- breeding females. $(A, B)$ Well-differentiated acinar adenocarcinoma (Ad) with local perineural invasion (arrows in $A, H \& E$ stain and $B$, adjacent section with keratin stain). (C) Adenosquamous mammary carcinoma showing acinar regions (Ad) interspersed with squamous regions (Sq) containing keratin pearls. $(D)$ Acinar adenocarcinoma displaying high mitotic rate (mitoses highlighted with arrows). (E-H) Representative histology of mammary carcinomas from $\mathrm{mBrca1} 1^{-/-} \mathrm{p} 53^{+/-}$breeding females. (E) Well-differentiated adenocarcinoma with acinar structure (H\&E stain). (F) Keratin staining of adjacent section shown in $E$ reveals patches of positively stained cells. $(G)$ Acinar adenocarcinoma with local invasion (arrows) into adjacent soft tissue (H\&E stain). (H) Acinar adenocarcinoma (H\&E stain) with occasional anaplastic cells (arrows). (I-L) Representative histology of tumors from $\mathrm{mBrca1} 1^{-/} \mathrm{p} 53^{-/-}$mice. (I) Adenocarcinoma (Ad) of salivary gland from male mouse adjacent to normal (N) gland tissue. (J) Subcutaneous carcinoma in male mouse. This same mouse was also afflicted with a B-cell lymphoma infiltrating the lungs (K: H\&E stain and $L:$ B220 stain). (M) Kaplan-Meier analysis of tumor-free survival of $\mathrm{mBrca1}^{-/-} \mathrm{Chk2}^{-/-}, \mathrm{mBrca1}^{-/-}$and $\mathrm{mBrCa1}^{+/-} \mathrm{Chk2}^{-/-}$or $\mathrm{Chk2}^{-/-}$females. Fifty percent of breeding $\mathrm{mBrca1}^{-/-} \mathrm{Chk2}^{-/-} \mathrm{fe}-$ males developed breast carcinoma. In addition, two $\mathrm{mBrCa1}^{-/-} \mathrm{Chk2}^{-/-}$females died at $393 \mathrm{~d}$ and $500 \mathrm{~d}$ of unknown causes due to autolysis and one $\mathrm{mBrca1}^{-1-} \mathrm{Chk2}^{-/-}$female was moribund of unknown pathology and sacrificed at 498 d. $(N)$ Kaplan-Meier analysis of tumor-free survival of $\mathrm{mBrCa1}^{-/-}$ $\mathrm{p} 53^{+/-}$breeding females, $\mathrm{mBrca1} 1^{-/} \mathrm{p} 53^{-/-}$ mice (male and female) and $p 53^{-/-}$mice (male and female).
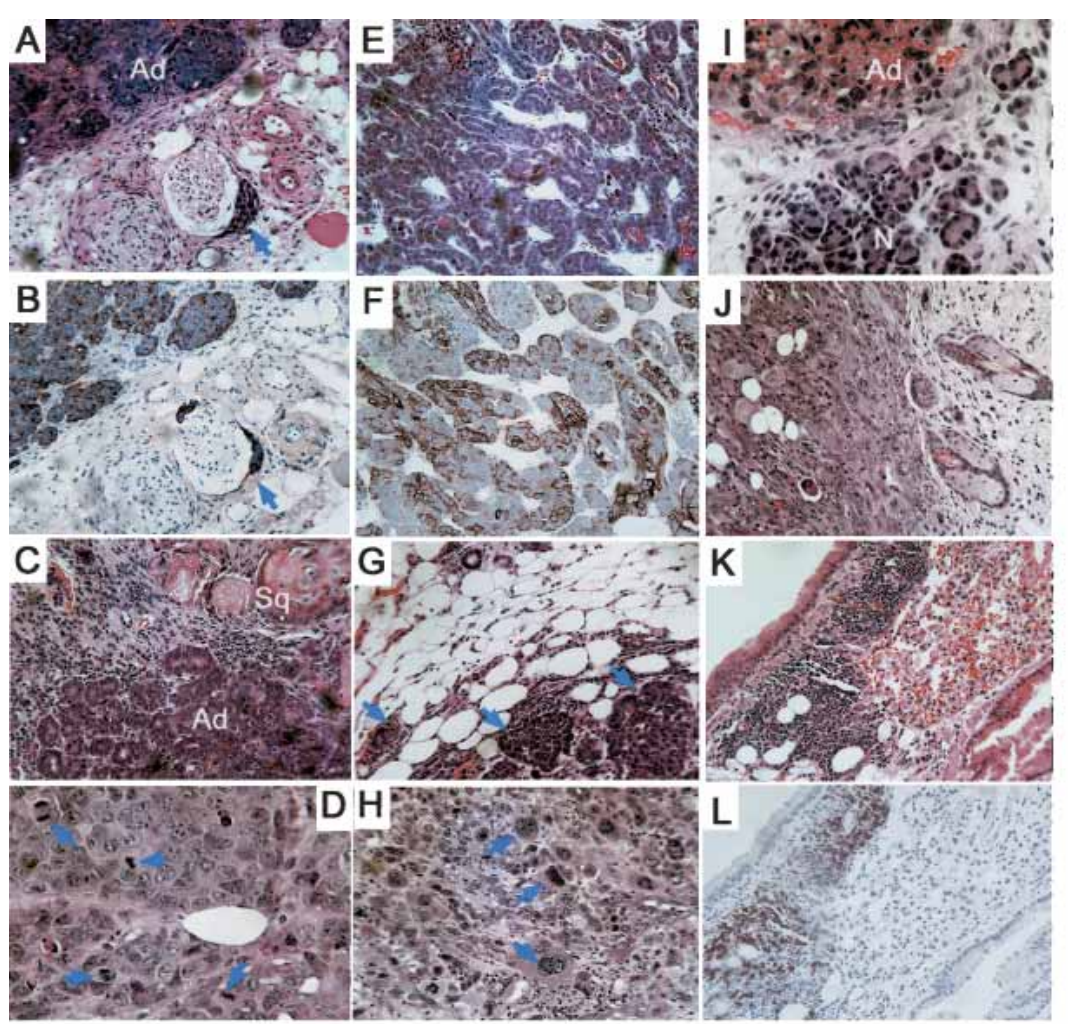

M
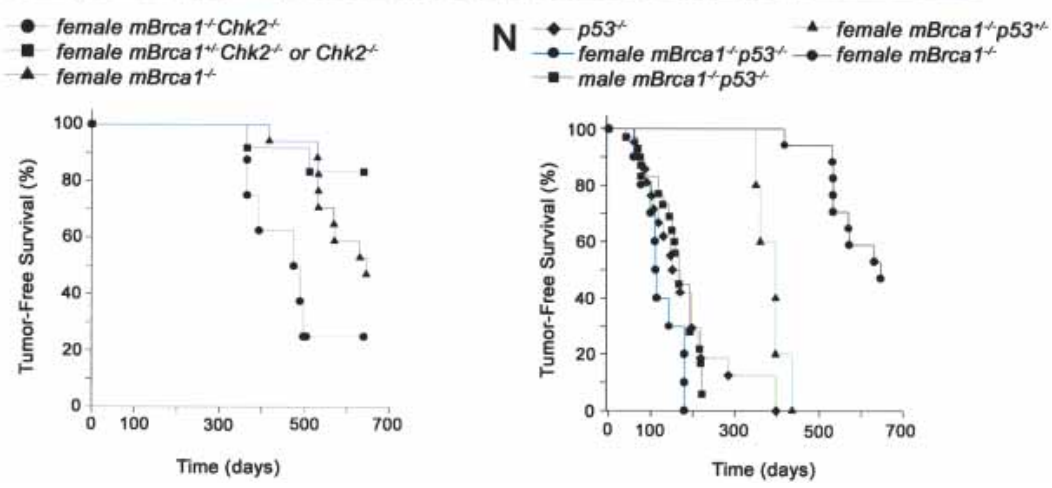

keeper" activity that, when defective, facilitates tumorigenesis through the survival and proliferation of cells with compromised genomic integrity (Kinzler and Vogelstein 1997).

In contrast to a previous study (Foray et al. 2003), our findings demonstrate that Brcal deficiency results in enhanced Chk2 phosphorylation and that Brcal is not required for Chk2 activation. Although Chk2 has been shown to interact with, phosphorylate, and colocalize with BRCA1 (Lee et al. 2000), this kinase-substrate relationship of Chk2 and Brcal in a DNA-damage signaling pathway implies an upstream function of Chk2 with respect to Brcal and cannot explain the cellular rescue of Brcal deficiency. Our finding supports a model in which inactivation of Chk2 and Brcal are cooperative and not epistatic in breast tumorigenesis. This finding seemingly contradicts previous epidemiological studies in which Chk2 and BRCA1 were ascribed to function in the same pathway. A Chk2-truncating variant (Chk21100delC) that has been found to be associated with low-penetrance breast cancer susceptibility appears to be epistatic with respect to BRCA1 mutations (Meijers-Heijboer et al. 2002; Vahteristo et al. 2002). However, separate analysis of Chk2 mutations in human breast cancer found an increased frequency of Chk2 mutations together with $p 53$ mutations in BRCA1-associated breast cancers compared with sporadic breast cancers (Sullivan et al. 2002). Furthermore, the associated loss of Chk2 expression in some breast tumors (Sullivan et al. 2002) suggests a potential role for epigenetic changes that could lead to the loss of Chk2 function and cooperation with BRCA1 mutations in neoplastic transformation. 


\section{Materials and methods}

\section{Mice}

Brca1 ${ }^{f 15-6}$ conditional mutant mice (Mak et al. 2000) were intercrossed with LckCre transgenic mice (Jackson Laboratory) or WapCre transgenic mice (Jackson Laboratory) to obtain tBrca1 $1^{-/-}$or $\mathrm{mBrca1}^{-/-}$mice, respectively. Subsequent crosses were performed using $\mathrm{Chk2}^{-/-}$mice (Hirao et al. 2002), Eu-bcl2-36 transgenic mice (Strasser et al. 1991), and $p 53^{-/-}$mice (Taconic). All mice studied were in a mixed 129/J $\times$ C57BL/6 genetic background and were genotyped by PCR (primer sequences and PCR conditions available upon request). Experimental cohorts were derived from littermates obtained from double-heterozygote breeders. Statistical significance of survival curves was assessed using the log-rank test. All experiments were performed in compliance with the Ontario Cancer Institute animal care committee guidelines.

\section{Flow cytometry}

Thymocytes, spleen, and lymph nodes were harvested from mice 5-8 wk of age and stained with the following monoclonal antibodies (Pharmingen): anti-CD4, anti-CD8, anti-Thy 1, anti$\mathrm{TCR} \alpha \beta$, and anti-B220. Fluorescence-activated cell sorting (FACS) analyses were performed using a FACS Calibur and cells were sorted using a FACSVantage flow cytometer (Becton Dickinson).

\section{Apoptosis and activation assays}

Thymocytes were either untreated or $\gamma$-irradiated and cultured for $8 \mathrm{~h}$ or $24 \mathrm{~h}$ prior to harvesting. Apoptosis was monitored by FACS analysis using Annexin V-FITC and propidium iodide (R\&D systems). Purified T cells obtained by cell sorting were activated with anti-CD3e $(10 \mu \mathrm{g} / \mathrm{mL}$ immobilized $)$ plus antiCD28 $(1 \mu \mathrm{g} / \mathrm{mL})$, or anti-CD3e (10 $\mu \mathrm{g} / \mathrm{mL}$ immobilized) plus murine IL-2 (100 units/mL, Biosource International) and proliferation assessed as described (Mak et al. 2000). Cell-cycle analysis was performed on anti-CD3 $\varepsilon+$ IL2 activated Thy $1^{+}$splenocytes using a BrdU flow kit (Pharmingen).

\section{Western analysis}

Western analysis was performed on thymocyte protein lysates using antibodies reactive to murine p53 (CM5, Novocastra), p21 (C-19, Santa Cruz), bax (N-20, Santa Cruz), actin (Sigma), and an affinity-purified rabbit polyclonal antibody raised against amino acids 81-95 of murine Chk2.

\section{Cytogenetic analysis}

Peripheral T cells were grown on plate-bound anti-CD $3 \varepsilon$ for 24 $\mathrm{h}$, followed by a 2-d culture in the presence of murine IL-2 (50 units $/ \mathrm{mL}$, Biosource International). The activated cells were treated with colcemid (Sigma) for $2 \mathrm{~h}$ and prepared for karyotyping (Dracopoli 1999).

\section{Histology}

Tumors and major organs were fixed in formalin and paraffin sections were stained with haematoxylin and eosin (H\&E) according to standard procedures. Tumor sections were stained with anti-Keratin (Chemicon).

\section{Acknowledgments}

We thank Sam Benchimol, Jose Luis de la Pompa, and Lenny Salmena for reviewing the manuscript; S. Cory for providing
Eu-bcl-2-36 transgenic mice; and D. Bouchard and Amro Shehabeldin for technical help. J.P.M. was supported by a Canadian Institute of Health Research Fellowship. M.P.H is supported by start-up grants from the National University of Singapore and Oncology Research Institute, NUMI, and a grant from Academic Research Fund, Faculty of Medicine, NUS, Singapore. This work was supported by Amgen Inc. and by a National Cancer Institute of Canada grant (TFPP no. 12000) to R.H.

The publication costs of this article were defrayed in part by payment of page charges. This article must therefore be hereby marked "advertisement" in accordance with 18 USC section 1734 solely to indicate this fact.

\section{References}

Bartek, J., Falck, J., and Lukas, J. 2001. Chk2 kinase-A busy messenger. Nature Rev. Mol. Cell Biol. 2: 877-886.

Bell, D.W., Varley, J.M., Szydlo, T.E., Kang, D.H., Wahrer, D.C., Shannon, K.E., Lubratovich, M., Verselis, S.J., Isselbacher, K.J., Fraumeni, J.F., et al. 1999. Heterozygous germ line hCHK2 mutations in Li-Fraumeni syndrome. Science 286: $2528-2531$.

Bochar, D.A., Wang, L., Beniya, H., Kinev, A., Xue, Y., Lane, W.S., Wang, W., Kashanchi, F., and Shiekhattar, R. 2000. BRCA1 is associated with a human SWI/SNF-related complex: Linking chromatin remodeling to breast cancer. Cell 102: $257-265$.

Brown, K.D., Rathi, A., Kamath, R., Beardsley, D.I., Zhan, Q., Mannino, J.L., and Baskaran, R. 2002. The mismatch repair system is required for S-phase checkpoint activation. Nature Genet. 33: 80-84.

Cao, L., Li, W., Kim, S., Brodie, S.G., and Deng, C.-X. 2003. Senescence, aging, and malignant transformation mediated by p53 in mice lacking the Brcal full-length isoform. Genes \& Dev. 17: 201-213.

Caspari, T. 2000. Checkpoints: How to activate p53. Curr. Biol. 10: R315-R317.

Chapman, M.S. and Verma, I.M. 1996. Transcriptional activation by BRCA1. Nature 382: 678-679.

Chehab, N.H., Malikzay, A., Appel, M., and Halazonetis, T.D. 2000. Chk2/hCds1 functions as a DNA damage checkpoint in G1 by stabilizing p53. Genes \& Dev. 14: 278-288.

Cressman, V.L., Backlund, D.C., Avrutskaya, A.V., Leadon, S.A., Godfrey, V., and Koller, B.H. 1999. Growth retardation, DNA repair defects, and lack of spermatogenesis in BRCA1deficient mice. Mol. Cell. Biol. 19: 7061-7075.

Crook, T., Crossland, S., Crompton, M.R., Osin, P., and Gusterson, B.A. 1997. p53 mutations in BRCA1-associated familial breast cancers. Lancet 350: 638-639.

Donehower, L.A., Harvey, M., Slagle, B.L., McArthur, M.J., Montgomery, C.A., Butel, J.S., and Bradley, A. 1992. Mice deficient for $\mathrm{p} 53$ are developmentally normal but susceptible to spontaneous tumours. Nature 356: 215-221.

Dracopoli, N.C. 1999. Current protocols in human genetics. John Wiley, New York.

Falck, J., Mailand, N., Syljuasen, R.G., Bartek, J., and Lukas, J. 2001. The ATM-chk2-cdc25A checkpoint pathway guards against radioresistant DNA synthesis. Nature 410: 842-847.

Foray, N., Marot, D., Gabriel, A., Randrianarison, V., Carr, A.M., Perricaudet, M., Ashworth, A., and Jeggo, P. 2003. A subset of ATM- and ATR-dependent phosphorylation events requires the BRCA1 protein. EMBO I. 22: 2860-2871.

Giaccia, A.J. and Kastan, M.B. 1998. The complexity of p53 modulation: Emerging patterns from divergent signals. Genes \& Dev. 12: 2973-2983. 
Gowen, L.C., Johnson, B.L., Latour, A.M., Sulik, K.K., and Koller, B.H. 1996. Brcal deficiency results in early embryonic lethality characterized by neuroepithelal abnormalities. $\mathrm{Na}$ ture Genet. 12: 191-194.

Greenblatt, M.S., Chappuis, P.O., Bond, J.P., Hamel, N., and Foulkes, W.D. 2001. TP53 mutations in breast cancer associated with BRCA1 or BRCA2 germ-line mutations: Distinctive spectrum and structural distribution. Cancer Res. 61: 4092-4097.

Hakem, R., de la Pompa, J.L., Sirard, C., Mo, R., Woo, M., Hakem, A., Wakeham, A., Potter, J., Reitmair, A., Billia, F., et al. 1996. The tumor suppressor gene Brcal is required for embryonic cellular proliferation in the mouse embryo. Cell 85: 1009-1023.

Hakem, R., de la Pompa, J.L., Elia, A., Potter, J., and Mak, T. 1997. Partial rescue of Brcal 5-6 early embryonic lethality by p53 or p21 null mutation. Nature Genet. 16: 298-302.

Hirao, A., Kong, Y.Y., Matsuoka, S., Wakeham, A., Ruland, J., Yoshida, H., Liu, D., Elledge, S.J., and Mak, T.W. 2000. DNA damage-induced activation of p53 by the checkpoint kinase Chk2. Science 287: 1824-1827.

Hirao, A., Cheung, A., Duncan, G., Girard, P.-M., Elia, A.J., Wakeham, A., Okada, H., Srakissian, T., Wong, J.A., Sakai, T., et al. 2002. Chk2 is a tumor suppressor that regulates apoptosis in both an Ataxia Telangiectasia mutated (ATM)Dependent and an ATM-independent manner. Mol. Cell. Biol. 22: 6521-6532.

Jack, M.T., Woo, R.A., Hirao, A., Cheung, A., Mak, T.W., and Lee, P.W.K. 2002. Chk2 is dispensable for p53-mediated G1 arrest but is required for a latent p53-mediated apoptotic response. Proc. Nat1. Acad. Sci. 99: 9825-9829.

Kinzler, K.W. and Vogelstein, B.W. 1997. Cancer-susceptibility genes. Gatekeepers and caretakers. Nature 386: 761-762.

Larson, J.S., Tonkinson, J.L., and Lai, M.T. 1997. A BRCA1 mutant alters G2-M cell cycle control in human mammary epithelial cells. Cancer Res. 57: 3351-3355.

Lee, J.S., Collins, K.M., Brown, A.L., Lee, C.-H., and Chung, J.H. 2000. hCds1-mediated phosphorylation of BRCA1 regulates the DNA damage response. Nature 404: 201-204.

Li, S., Ting, N.S.Y., Zheng, L., Chen, P.-L., Ziv, Y., Shiloh, Y., Lee E.Y.-H.P., and Lee, W.-H. 2000. Functional link of BRCA1 and ataxia telangiectasia gene product in DNA damage response. Nature 406: 210-214.

Liu, C.Y., Flesken-Nikitin, A., Li, S., Zeng, Y., and Lee, W.H. 1996. Inactivation of the mouse Brcal gene leads to failure in the morphogenesis of the egg cylinder in early postimplantation development. Genes \& Dev. 10: 1835-1841.

Ludwig, T., Chapman, D.L., Papaioannou, V.E, and Efstratiadis, A. 1997. Targeted mutations of breast cancer susceptibility gene homologs in mice: Lethal phenotypes of Brca1, Brca2, Brca1/Brca2, Brca1/p53, and Brca2/p53 nullizygous embryos. Genes \& Dev. 11: 1226-1241.

Ludwig, T., Fisher, P., Ganesan, S., and Efstratiadis, A. 2001. Tumorigenesis in mice carrying a truncating Brcal mutation. Genes \& Dev. 15: 1188-1193.

Mak, T.W., Hakem, A., McPherson, J.P., Shehabeldin, A., Zablocki, E., Migon, E., Duncan, G.S., Bouchard, D.S., Wakeham, A., Cheung, A., et al. 2000. Brcal required for T cell lineage development but not TCR loci rearrangement. $\mathrm{Na}$ ture Immunol. 1: 77-82.

Malkin, D., Li, F.P., Strong, L.C., Fraumeni Jr., J.F., Nelson, C.E., Kim, D.H., Kassel, J., Gryka, M.A., Bischoff, F.Z., Tainsky, M.A., et al. 1990. Germ line p53 mutations in a familial syndrome of breast cancer, sarcomas, and other neoplasms. Science 250: 1233-1238.

McGowan, C.H. 2002. Checking in on cds1 (chk2): A check- point kinase and tumor suppressor. Bioessays 24: 502-511. Meijers-Heijboer, H., van den Ouweland, A., Klijn, J., Wasielewski, M., de Snoo, A., Oldenburg, R., Hollestelle, A., Houben, M., Crepin, E., van Veghel-Plandsoen, M., et al. 2002. Low-penetrance susceptibility to breast cancer due to Chek $2{ }^{\star} 1100$ delC in noncarriers of BRCA1 or BRCA2 mutations. Nature Genet. 31: 55-59.

Monteiro, A.N.A., August, A., and Hanafusa, H. 1996. Transcriptional activation by BRCA1. Proc. Natl. Acad. Sci. 93: 13595-13599.

Moynahan, M.E., Chiu, J.W., Koller, B.H., and Jasin, M. 1999. Brcal controls homology-directed DNA repair. Mol. Cell 4: 511-518.

Nyberg, K.A., Michelson, R.J., Putnam, C.W., and Weinert, T.A. 2002. Toward maintaining the genome: DNA damage and replication checkpoints. Annu. Rev. Genet. 36: 617-656.

Pao, G.M., Janknecht, R., Ruffner, H., Hunter, T., and Verma, I.M. 2000. CBP/p300 interact with and function as transcriptional coactivators of BRCA1. Proc. Natl. Acad. Sci. 97: 1020-1025.

Rich, T., Allen, R.L., and Wyllie, A.H. 2000. Defying death after DNA damage. Nature 407: 777-783.

Scully, R. and Livingston, D.M. 2000. In search of the tumour suppressor functions of BRCA1 and BRCA2. Nature 408: 429-432.

Scully, R., Anderson, S.F., Chao, D.M., Wei, W., Ye, L., Young, R.A., Livingston, D.M., and Parvin, J.D. 1997a. BRCA1 is a component of the RNA polymerase II holoenzyme. Proc. Natl. Acad. Sci. 94: 5605-5610.

Scully, R., Chen, J., Ochs, R.L., Keegan, K., Hoekstra, M., Feunteun, J., and Livingston, D.M. 1997b. Dynamic changes of BRCA1 subnuclear location and phosphorylation state are initiated by DNA damage. Cell 90: 425-435.

Shen, S.X., Weaver, Z., Xu, X., Li, C., Weinstein, M., Chen, L., Guan, X.Y., Ried, T., and Deng, C.X. 1998. A targeted disruption of the murine Brcal gene causes $\gamma$-irradiation hypersensitivity and genetic instability. Oncogene 17: 3115-3124.

Shieh, S.Y., Ahn, J., Tamai, K., Taya, Y., and Prives, C. 2000. The human homologs of checkpoint kinases Chk1 and Cds1 (Chk2) phosphorylate p53 at multiple DNA damage-inducible sites. Genes \& Dev. 14: 289-300.

Shiloh, Y. 2003. ATM and related protein kinases: Safeguarding genome integrity. Nat. Rev. Cancer 3: 155-168.

Somasundaram, K., Zhang, H., Zeng, Y.-X., Houvras, Y., Peng, Y., Zhang, H, Wu, G.S., Licht, J.D., Weber, B.L., and El-Deiry, W.S. 1997. Arrest of the cell cycle by the tumour-suppressor BRCA1 requires the CDK-inhibitor p21Waf1/Cip1. Nature 389: $187-190$.

Srivastava, S., Zou, Z.Q., Pirollo, K., Blattner, W., and Chang, E.H. 1990. Germ-line transmission of a mutated p53 gene in a cancer-prone family with Li-Fraumeni syndrome. Nature 348: 747-749.

Strasser, A., Harris, A.W., and Cory, S. 1991. bcl-2 transgene inhibits cell death and perturbs thymic self-censorship. Cell 67: 889-899.

Sullivan, A., Yuille, M., Repellin, C., Reddy, A., Reelfs, O., Bell, A., Dunne, B., Gusterson, B.A., Osin, P., Farrell, P.J., et al. 2002. Concomitant inactivation of p53 and Chk2 in breast cancer. Oncogene 21: 1316-1324.

Takai, H., Naka, K., Okada, Y., Watanabe, M., Harada, N., Saito, S., Anderson, C.W., Appella, E., Nakanishi, M., Suzuki, H., et al. 2002. Chk2-deficient mice exhibit radioresistance and defective p53-mediated transcription. EMBO J. 21: 5195-5205.

Vahteristo, P., Bartkova, J., Eerola, H., Syrjakoski, K., Ojala, S., Kilpivaara, O., Tamminen, A., Kononen, J., Aittomaki, K., 
Heikkila, P., et al. 2002. A CHEK2 genetic variant contributing to a substantial fraction of familial breast cancer. Am. J. Hum. Genet. 71: 432-438.

Venkitaraman, A.R. 2002. Cancer susceptibility and the functions of BRCA1 and BRCA2. Cell 108: 171-182.

Vousden, K.H. and Lu, X. 2002. Live or let die: The cell's response to p53. Nat. Rev. Cancer 2: 594-604.

Wang, Y., Cortez, D., Yazdi, P., Neff, N., Elledge, S.J., and Qin, J. 2000. BASC, a super complex of BRCA1-associated proteins, involved in the recognition and repair of aberrant DNA structures. Genes \& Dev. 14: 927-939.

Welcsh, P.L., Owens, K.N., and King, M.C. 2000. Insights into the function of BRCA1 and BRCA2. Trends Genet. 16: 6974.

Xu, X., Wagner, K.U., Larson, D., Weaver, Z., Li, C., Ried, T., Hennighausen, L., Wynshaw-Boris, A., and Deng, C.X. 1999. Conditional mutation of Brcal in mammary epithelial cells resulted in blunted ductal morphogenesis and tumour formation. Nature Genet. 22: 37-43.

Xu, X., Qiao, W., Linke, S.P., Cao, L., Li, W.-M., Furth, P.A., Harris, C.C., and Deng, C.X. 2001. Genetic interactions between tumour suppressors Brcal and p53 in apoptosis, cell cycle and tumorigenesis. Nature Genet. 28: 266-271.

Yang, S., Kuo, C., Bisi, J.E., and Kim, M.K. 2002. PML-dependent apoptosis after DNA damage is regulated by the checkpoint kinase hCds1/Chk2. Nat. Cell Biol. 4: 865-870.

Yarden, R.I. and Brody, L.C. 1999. BRCA1 interacts with components of the histone deacetylase complex. Proc. Natl. Acad. Sci. 96: 4983-4988.

Zhong, Q., Chen, C.-F., Yi, S., Chen, Y., Wang, C.-C., Xiao, J., Chen, P.-L., Sharp, Z.D., and Lee, W.H. 1999. Association of BRCA1 with the hRad50-hMre11-p95 complex and the DNA damage response. Science 285: 747-750.

Zhou, B.B.S. and Elledge, S.J. 2000. The DNA damage response: Putting checkpoints in perspective. Nature 408: 433-439. 


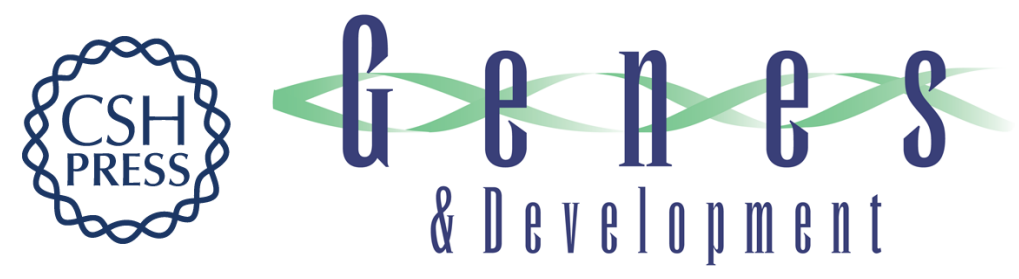

\section{Collaboration of Brca1 and Chk2 in tumorigenesis}

John Peter McPherson, Bénédicte Lemmers, Atsushi Hirao, et al.

Genes Dev. 2004, 18:

Access the most recent version at doi:10.1101/gad.1192704

\section{Supplemental http://genesdev.cshlp.org/content/suppl/2004/05/07/1192704.DC1 \\ Material \\ References This article cites 58 articles, 23 of which can be accessed free at: http://genesdev.cshlp.org/content/18/10/1144.full.html\#ref-list-1 \\ License}

Email Alerting Receive free email alerts when new articles cite this article - sign up in the box at the top Service right corner of the article or click here.

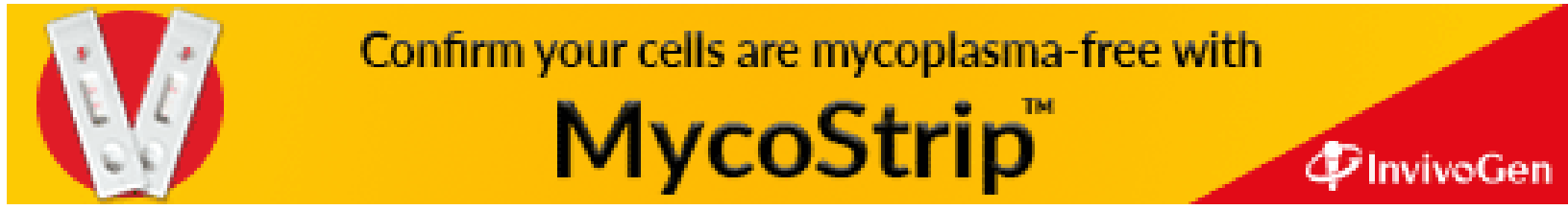

